\section{Where next for Alvey?}

BRITAIN's Alvey programme, aimed at strengthening the information technology industries through collaborative research with the universities, appears to be at a critical stage. Last week's Alvey conference made clear that the programme, now halfway through its five-year life, has produced enough successes to excite government, universities and industry. But nobody is sure how to keep the momentum going to ensure long-term industrial success.

The 600 delegates at the conference at the University of Sussex were clearly optimistic about the future. The Alvey programme is a unique attempt to break down the barriers between the universities and industry in key areas of information technology: very-large-scale integrated circuits, software engineering; intelligent knowledge-based systems; and man/ machine interfaces. To ensure industrial involvement, even the smaller basic research projects carried out at universities must have an industrial "uncle" — someone from industry who will alert colleagues when an idea begins to look worth industrial development.

Three hundred and three projects are now under way at a cost of almost $£ 200$ million to the government plus a somewhat smaller amount from industry. One hundred and eight companies are participating alongside 53 universities and polytechnics (Imperial College, Edinburgh and Cambridge form the first league), a

\section{academics protest}

sities be given real, not merely symbolic, control over their budgets and the right to choose their own officials, rather than have them appointed by the state.

A further suggestion is that student grants should be pegged to keep pace with inflation and that less weight should go to means testing of family income. This would favour better-off families and is liable to be opposed by Party hard-liners.

Another proposal raises the whole question of the relationship between workers and intellectuals in a socialist state. In Hungary, entitlements to annual leave, pension rights and priority for housing are all related to length of service at a particular enterprise. Young graduates entering the system thus find themselves disadvantaged because they are five years behind in acquiring benefits compared with a worker who entered employment direct from school. The Szeged group is now asking for the years of study to be counted in the employment record — a seemingly modest proposal but one with clear political overtones. level of cooperation that Minister of State for Information Technology Geoffrey Pattie described as "probably unprecedented in peacetime". But as John Alvey, who originally proposed the programme, put it, "we have won some victories, but haven't won the war". The test will be the international marketplace. If saleable products cannot be produced, then Britain's industrial position will fall back still further.

Much discussion centred on what must be done to prevent this happening. Those actively involved in research tended to concentrate on the details: is there not, for example, an easier way to cope with drawing up cooperative agreements? Big delays have been caused. And would it not be wiser to have a central research institute instead of distributing work throughout the participating laboratories? Advantages of the former are that it quickly creates a critical mass of expertise and avoids duplication. But it can too easily become an ivory tower. The really big questions, spelled out by Pattie, were of government support and the balance between national and international programmes. Although everyone would like funding to continue, the pre-competitive research of Alvey must be commercially exploited and the postgraduates who have been trained persuaded to move on to industry.

For the balance between international and national funding, critical decisions must be made soon. The huge industrial high-technology programmes, ESPRIT and RACE (for information and communication technology), lie within the European "research and development framework programme", designed to shape policy for the next five years. The outline of the programme is now before the European Community's science ministers. Where will the post-Alvey programme fit? According to Pattie, international programmes cannot substitute for national ones, for the latter are necessary to give strength in collaborative projects.

A formal "After Alvey" committee, chaired by Sir Austin Bide, has already been set up and will report in the autumn. Submit your evidence to Sir Austin, said Pattie: "no decision has been predetermined" and "real decisions" will be made. But as one iconoclast at the meeting put it, "can any number of collaborative programmes be a substitute for the rationalization of Europe's information technology industries?" Without markets and companies of the size found in United States and Japan, can Europe's excellent research ever be successfully exploited?

Alun
Chinese science

\section{Legal protection for scientists}

China is to have a new law to protect societies from "outside interference". Addressing the third national congress of the Chinese Association for Science and Technology (CAST) last month, Song Jian, minister in charge of the State Science and Technology Commission, noted that the proposed law would give "official status to scholarly societies and define their role". It would regulate their relationship with the Communist Party, the government and state-owned collective and individual enterprises, Song said, as well as guaranteeing that their work could proceed "along normal lines".

China has 138 learned societies and organizations with 1.8 million members, who, in their turn, according to Song, are "in touch with a further five million scientists and technicians". The need for legal protection for scientific and learned research has been much discussed in the Chinese media during the past two months, in connection with the thirtieth anniversary of the launching of the "double hundred" policy ("Let a hundred flowers bloom, let a hundred schools of thought contend") which in recent years has been restored to official favour. The Constitution of the Peoples' Republic of China (Article 47) stipulates that "citizens have freedom to engage in scientific research, literary and artistic creation and other cultural activities", but this did not save scientists and scholars during the cultural revolution. Promulgating a specific law to cover learned activities, however, is felt to be sufficient, in the words of the People's Daily, to "ensure the implementation of the 'double hundred' without any intervention by or hindrance from either 'leftist' or 'rightist' tendencies".

The new law, and the "double hundred" policy itself will not give the scholars total independence. Social scientists, economists and philosophers will be allowed, within their learned environments, to investigate and consider non-Marxist theories. If they are asked to provide recommendations for practical implementation in production or society, however, they must base their proposals on sound Marxist principles. The natural scientists come off somewhat better, since, according to the Peoples' Daily and other leading commentators, the natural sciences can only flourish properly when kept clear of misleading ideological and philosophical labels. Frequent reference has been made recently to the Qingdao genetics forum of August 1956, which broke the monopoly of Lysenkoism in China as the exemplar of the proper "contention" of scientific ideas.

Vera Rich 